\title{
The Necessity for Taxable Capacity Assessment for the Segments of the Insurance Market
}

\author{
Galimardanova Y. M. \\ Kazan Federal University, Institute of Management, Economics and Finance, Kazan, 420008, Russia
}

Khafizova A.R.

Kazan Federal University, Institute of Management, Economics and Finance, Kazan, 420008, Russia

Salmina S.V.

Kazan Federal University, Institute of Management, Economics and Finance, Kazan, 420008, Russia

Emails: hafiwka@mail.ru

\section{Doi:10.5901/mjss.2014.v5n24p407}

Abstract

This paper describes the current taxation problems of the insurance market constituents and finding solutions to these problems. Perfection of tax regulation for the insurance market constituents bases on quantifying its taxable capacity by major market segments.

Keywords: insurance market, insurance market constituents, taxation, tax regulation, taxable capacity.

\section{Introduction}

The practice to implement state tax regulation under conditions of insurance market shall, from our point of view, be based on distinct understanding of potential tax abilities of the insurance market. Therefore, the necessity for assessment of insurance market taxable capacity is reasonably sufficient and in the long term management of tax risks at the enterprises of the insurance industry. [9] The necessity for assessment of insurance market taxable capacity, in its turn, requires the definition "taxable capacity" to be specified.

\section{Theory}

Studying and sizing the taxable capacity in terms of today's Russia is quite a new scientific field. Therefore, there are a lot of papers in the Russian and foreign practice that attempt to formulate the definition "taxable capacity".

Summarising the dedicated research data available in the modern domestic theory, we think that it is practical to identify such main approaches to define "taxable capacity" as:

- Maximum possible tax payment on a given territory (fiscal approach);

- Potential budget per-capita income, which may be earned from inter-budgetary relations (inter-budgetary approach); and

- Resources subject to be budgetary accumulated through tax payments (resource approach).

In addition, we don't challenge other approaches to define "taxable capacity" to be available, however we believe that generally the above mentioned approaches are the trends for studying this issue that may include the alternate approaches as well.

It should be noted that the theoretical and applied study of taxable capacity includes not only this definition but also its quantitative estimation (calculation). Most of the existing estimation methods of the taxable capacity assume its assessment on a nationwide scale and base on the estimation of the taxable capacity of the country-subdividing regions. At that, the theory and practice of budgetary and tax regulation suggest that the advanced economies have amassed the experience in quantitative estimation of taxable capacity of the regions and in respective inter-regional comparisons and classifications. Analysis of this experience provides a number of key methodological postulates being basis for the 
quantitative determination of taxable capacity.

Based on individual approaches, procedures, formulas to assess the taxable capacity proposed by different authors, we have summarised, analysed and systematised the main taxable capacity assessment techniques and provided with a comparison characteristic in terms of advantages and disadvantages as shown in Table 1.

Table 1. Assessment techniques for insurance market taxable capacity and their comparison characteristic

\begin{tabular}{|c|c|c|c|}
\hline Technique & Description & Advantages & Disadvantages \\
\hline \multicolumn{4}{|c|}{ 1. Assessment techniques of insurance market taxable capacity at a macroeconomic level (state-wide) } \\
\hline \multicolumn{4}{|c|}{ 1.1. Assessment techniques based on economic income indexes } \\
\hline $\begin{array}{l}\text { GRP-based assessment (Gross } \\
\text { Regional Product or income } \\
\text { produced) }\end{array}$ & $\begin{array}{l}\text { As the multiplication of a } \\
\text { share taken by the insurance } \\
\text { industry in the GRP of a } \\
\text { country and the mean } \\
\text { effective tax rate over the } \\
\text { country. }\end{array}$ & - Easy calculation & $\begin{array}{l}\text { - Lack of sufficient statistic data; } \\
\text { - The GRP volume does not consider the disequilibrium } \\
\text { of tax bases and taxation rates in different regions; } \\
\text { - The calculation of the GRP value does not include tax } \\
\text { efforts of regional insurance markets; and } \\
\text { - The GRP value is published with an error. }\end{array}$ \\
\hline $\begin{array}{l}\text { Assessment based on per- } \\
\text { capita income (earned or } \\
\text { disposable income) }\end{array}$ & $\begin{array}{l}\text { As the multiplication of a } \\
\text { share taken by the insurance } \\
\text { industry in the GRP of a } \\
\text { country or a region, the mean } \\
\text { effective tax rate over the } \\
\text { country and the population } \\
\text { rate of the country or the } \\
\text { region. }\end{array}$ & $\begin{array}{l}\text { - Easy calculation; } \\
\text { - Dependence of } \\
\text { budget revenues of a } \\
\text { country or a region on } \\
\text { income level } \\
\end{array}$ & $\begin{array}{l}\text { - Lack of sufficient statistic data; } \\
\text { - The GRP volume does not consider the disequilibrium } \\
\text { of tax bases and taxation rates in different regions; } \\
\text { - The calculation of the GRP value does not include tax } \\
\text { efforts of regional insurance markets; } \\
\text { - The GRP value is published with an error; and } \\
\text { - The population rate does not take into account that the } \\
\text { entire population employs insurance services }\end{array}$ \\
\hline $\begin{array}{l}\text { TTR-based assessment (total } \\
\text { taxable resources) }\end{array}$ & $\begin{array}{l}\text { On the basis of total taxable } \\
\text { resources }\end{array}$ & $\begin{array}{l}\text { - More accurate } \\
\text { reflection of actual } \\
\text { taxable resource } \\
\text { volume }\end{array}$ & $\begin{array}{l}\text { - Calculations require a sufficiently large amount of } \\
\text { statistic data; and } \\
- \text { - Calculations take more hours. }\end{array}$ \\
\hline \multicolumn{4}{|c|}{ 1.2. Assessment techniques based on a representative taxation system } \\
\hline $\begin{array}{l}\text { Assessment based on building a } \\
\text { representative system of tax } \\
\text { indexes }\end{array}$ & $\begin{array}{l}\text { On the basis of total (federal, } \\
\text { regional, local) taxes, which } \\
\text { uses estimated taxation base } \\
\text { and countrywide average tax } \\
\text { rate for each particular tax. }\end{array}$ & \begin{tabular}{|l|} 
- Reliability and \\
objectivity of \\
assessment; and \\
- Real possibilities to \\
form taxation bases are \\
taken into \\
consideration. \\
\end{tabular} & $\begin{array}{l}\text { - High labour intensity of calculations; } \\
\text { - Lack of sufficient statistic data on taxation bases; and } \\
\text { - High requirements to data comparability. } \\
\end{array}$ \\
\hline $\begin{array}{l}\text { Assessment based on relative } \\
\text { tax revenues }\end{array}$ & $\begin{array}{l}\text { On the basis of total taxation } \\
\text { bases and rates for individual } \\
\text { taxes (major returns). }\end{array}$ & $\begin{array}{l}\text { - Real possibilities to } \\
\text { form taxation bases are } \\
\text { taken into } \\
\text { consideration; and } \\
\text { - Less information } \\
\text { required for } \\
\text { calculations. }\end{array}$ & $\begin{array}{l}\text { - High labour intensity of calculations; } \\
\text { - Lack of sufficient statistic data on taxation bases; } \\
\text { - High requirements to data comparability; and } \\
\text { - The technique is less reliable and intrinsic. }\end{array}$ \\
\hline \begin{tabular}{|l|} 
Assessment based on \\
correlation-regression analysis
\end{tabular} & \begin{tabular}{|l|} 
On the basis of a model of \\
functional relationship \\
between some factors that \\
influence on the taxable \\
capacity value, e.g. taxation \\
base for a tax payable by \\
insurance market constituents \\
and actual receipts of related \\
payments. \\
\end{tabular} & $\begin{array}{l}\text { - Significant objectivity; } \\
\text { - Revealing } \\
\text { dependence between } \\
\text { factors; and } \\
\text { - Low labour intensity. } \\
\end{array}$ & $\begin{array}{l}\text { - The technique is complicated for usage due to } \\
\text { ambiguity of factor selection; and } \\
\text { - Hard to compare the results by the regions. }\end{array}$ \\
\hline \multicolumn{4}{|c|}{ 1.3. Assessment techniques based on conversion of tax form data } \\
\hline $\begin{array}{l}\text { Assessment based on additive } \\
\text { property of taxable capacity }\end{array}$ & $\begin{array}{l}\text { As total taxable capacities of } \\
\text { individual taxes payable by } \\
\text { insurance market } \\
\text { constituents. In the reduced } \\
\text { form, the taxable capacity is a } \\
\text { sum of total taxes paid by } \\
\text { insurance market constituents } \\
\text { to all the budgets. }\end{array}$ & \begin{tabular}{|l|} 
- Availability of \\
database for \\
calculations; \\
- Predictability through \\
analysis of taxation \\
base; and \\
- Distinction between \\
tax types results in \\
sufficiently accurate \\
figures.
\end{tabular} & $\begin{array}{l}\text { - The technique bases on actual data and does not } \\
\text { consider the current and future states of taxation base. }\end{array}$ \\
\hline
\end{tabular}




\begin{tabular}{|c|c|c|c|}
\hline Technique & \begin{tabular}{|l|l} 
Description & 1 \\
\end{tabular} & Advantages & Disadvantages \\
\hline $\begin{array}{l}\text { Assessment based on a } \\
\text { simplified method }\end{array}$ & $\begin{array}{l}\text { As total taxable capacities of } \\
\text { limited 'underlying' taxes } \\
\text { subject to be paid by } \\
\text { insurance market constituents } \\
\text { with further revaluation of } \\
\text { taxable capacity over the } \\
\text { remaining taxes. }\end{array}$ & \begin{tabular}{|l|} 
- Availability of \\
database for \\
calculations; and \\
- Data for calculations \\
are taken from a single \\
data source.
\end{tabular} & $\begin{array}{l}\text { - The technique bases on actual data and does not } \\
\text { consider the current and future states of taxation base; } \\
\text { and } \\
\text { - The technique does not cover the total taxes and their } \\
\text { taxation base. }\end{array}$ \\
\hline $\begin{array}{l}\text { Assessment based on an actual } \\
\text { method }\end{array}$ & $\begin{array}{l}\text { On the basis of the amount of } \\
\text { actual tax payments from all } \\
\text { insurance market constituents } \\
\text { inclusive of increase in tax } \\
\text { liabilities. }\end{array}$ & $\begin{array}{l}\text { - Easy calculation; and } \\
\text { - Availability of } \\
\text { database for } \\
\text { calculations. }\end{array}$ & $\begin{array}{l}\text { - The calculation uses actual data only; and } \\
\text { - Complicated prediction since the information on } \\
\text { taxation base is not in use. }\end{array}$ \\
\hline \multicolumn{4}{|c|}{ 1.4. Assessment techniques based on correction of actual tax payments in the region } \\
\hline $\begin{array}{l}\text { Assessment based on } \\
\text { correction of the tax payments } \\
\text { collected in the base year }\end{array}$ & $\begin{array}{l}\text { On the basis of actual tax } \\
\text { payments made by all } \\
\text { insurance market constituents } \\
\text { in the base year as corrected } \\
\text { in line with the subsequent } \\
\text { amendments of laws and } \\
\text { regulations }\end{array}$ & $\begin{array}{l}\text { - Relatively easy } \\
\text { calculation; and } \\
\text { - Availability of } \\
\text { database for } \\
\text { calculations. }\end{array}$ & $\begin{array}{l}\text { - The calculation is sufficiently subjective; } \\
\text { - The calculation does not take tax activity of regions into } \\
\text { account; and } \\
\text { - Low reliability and accuracy of calculation results. }\end{array}$ \\
\hline \multicolumn{4}{|c|}{ 2. Assessment techniques of taxable capacity at a microeconomic level (enterprise) } \\
\hline $\begin{array}{l}\text { Assessment of taxable capacity } \\
\text { based on the tax burden of an } \\
\text { insurance market constituent }\end{array}$ & $\begin{array}{l}\text { Assessment of taxable } \\
\text { capacity based on the tax } \\
\text { burden of an insurance } \\
\text { market constituent }\end{array}$ & $\begin{array}{l}\text { Assessment of taxable } \\
\text { capacity based on the } \\
\text { tax burden of an } \\
\text { insurance market } \\
\text { constituent }\end{array}$ & $\begin{array}{l}\text { Assessment of taxable capacity based on the tax burden } \\
\text { of an insurance market constituent }\end{array}$ \\
\hline $\begin{array}{l}\text { Assessment of taxable capacity } \\
\text { based on the taxable resources } \\
\text { of an insurance market } \\
\text { constituent }\end{array}$ & $\begin{array}{l}\text { Assessment of taxable } \\
\text { capacity based on the taxable } \\
\text { resources of an insurance } \\
\text { market constituent }\end{array}$ & $\begin{array}{l}\text { Assessment of taxable } \\
\text { capacity based on the } \\
\text { taxable resources of an } \\
\text { insurance market } \\
\text { constituent }\end{array}$ & $\begin{array}{l}\text { Assessment of taxable capacity based on the taxable } \\
\text { resources of an insurance market constituent }\end{array}$ \\
\hline
\end{tabular}

The study has revealed that the common calculation method is not available for such essential measure as the taxable capacity so far. There are various approaches and suggestions on how to calculate the taxable capacity of a region, territory, municipality, tax payer etc.

It should be noted that the method of correlation - regression analysis presented in the works of authors such as Zhang Q., Peng C., Kim S., Lee J., Luo Y., Nie J., Young E.R. [1; 4; 6; 7; 10; 11]

We believe that it is feasible to apply these approaches to calculate the taxable capacity of the insurance market. To be noticed is that not all of the existing techniques may be used for assessment of insurance market taxable capacity. Techniques that base on the estimation of value added for individual industries can be distinguished among them. In addition, some calculation methods require information, which is hard to get. Studying the taxable capacity assessment techniques enabled their grouping and adapting for the analysis of taxable capacity for insurance market and verification of their advantages and disadvantages. We believe that taxable capacity can be analysed both at the macroeconomic level, i.e. the entire national insurance market or individual regions, and at the microeconomic level, which means combined analysis of individual insurance market constituents.

\section{Results}

Thus, from all our assessment techniques, the taxable capacity of insurance market may be calculated by the assessment techniques based on a representative taxation system and analysis, where the tax form data are converted with particular assumptions. The following assumptions can be identified: Only limited number of insurance market constituents - insurance companies - may be analysed to facilitate the assessment of insurance market taxable capacity as no tax reporting is provided for other insurance constituents. Furthermore, from all taxes subject to be paid by insurance companies, the tax reporting is formed generally from the income tax. Regarding other regional and local taxes to be paid by insurance companies, data are published without breakdown by their types. The tax reporting does not contain data of taxation bases with respect to the taxes to be paid by insurance companies, which complicates the prediction. Moreover, in practice the concept of isolated double insurance and insurance in the implementation of investment funds in the Russian economy, which is also true today. [3] 
Table 2 presents the values of insurance market taxable capacity for the Republic of Tatarstan in terms of income tax paid by insurance companies from 2008 through 2012 as provided in columns with different techniques. In accordance with the assessment technique based on representative system, the calculation of taxable capacity for the income tax paid by insurance companies of the Republic of Tatarstan uses data on profits of insurance companies subject to imposition of taxes and respective income tax rates.

Table 2. Quantification of taxable capacity for the insurance market of the Republic of Tatarstan with respect to the income tax paid by insurance companies over a period of 2008 through 2012

\begin{tabular}{|c|c|c|c|c|}
\hline \multirow{2}{*}{ Year } & \multicolumn{3}{|c|}{ Taxable capacity for income tax (mln. rubles) } \\
\cline { 2 - 5 } & $\begin{array}{c}\text { Assessment based on } \\
\text { representative system of } \\
\text { tax values }\end{array}$ & $\begin{array}{c}\text { Assessment based on correlation- } \\
\text { regression analysis }\end{array}$ & $\begin{array}{c}\text { Calculation based on additive } \\
\text { property of taxable capacity }\end{array}$ & $\begin{array}{c}\text { Assessment based on } \\
\text { actual method }\end{array}$ \\
\hline 2008 & 74,2 & 76,4 & 92,9 & 86,2 \\
\hline 2009 & 120,4 & 125,3 & 134,4 & 143,1 \\
\hline 2010 & 241,8 & 245,8 & 256,1 & 262,3 \\
\hline 2011 & 221,3 & 226,7 & 238,6 & 245,4 \\
\hline 2012 & 180,9 & 185,4 & 195,4 & 204,2 \\
\hline
\end{tabular}

The correlation-regression analysis produced a linear function of dependence of two variables being taxable profit of the Tatarstan's insurance companies liable to tax over the period under review and the income tax rate. The calculation based on additive property of taxable capacity used formal tax data, particularly, accrued income taxes over the relevant period including corrections to the amount of related actual tax payments received. Actual income taxes received were taken as a basis for the assessment of taxable capacity based on actual method including corrections for increase in tax liabilities of the previous year: from the formal tax data 1-NOM "About receiving tax payments and other revenues by the budget system of the Russian Federation from the primary industries" and 4-NOM "Report of tax, due, fine liabilities and tax sanctions into the budget system of the Russian Federation over the primary business activities".

The results of Income Tax Capacity calculation for the insurance companies of the Republic of Tatarstan based on the techniques provided were used for analysis of how to implement the Income Tax Capacity by comparing the calculation data with actual return of corporate income tax over the respective years. The resulting data are given in the below Table 3.

Table 3. Results of Corporate Income Tax Capacity assessment for the insurance companies of the Republic of Tatarstan over a period of 2008 through 2012

\begin{tabular}{|c|c|c|c|c|c|}
\hline & \multirow{2}{*}{$\begin{array}{c}\text { Total returns of } \\
\text { Year }\end{array}$} & \multicolumn{4}{|c|}{$\begin{array}{c}\text { Implementation of Corporate Income Tax Capacity } \\
\text { (departure from actual value), (mln. rubles) }\end{array}$} \\
\cline { 3 - 6 } & $\begin{array}{c}\text { corate income tax } \\
\text { (mln. rubles) }\end{array}$ & $\begin{array}{c}\text { Assessment based on } \\
\text { building a representative } \\
\text { system of tax values }\end{array}$ & $\begin{array}{c}\text { Assessment based on } \\
\text { correlation-regression } \\
\text { analysis }\end{array}$ & $\begin{array}{c}\text { Calculation based on } \\
\text { additive property of } \\
\text { taxable capacity }\end{array}$ & $\begin{array}{c}\text { Assessment based } \\
\text { on actual method }\end{array}$ \\
\hline 2008 & 72,8 & 1,9 & 4,9 & 27,6 & 18,4 \\
\hline 2009 & 117,6 & 2,4 & 6,5 & 14,3 & 21,7 \\
\hline 2010 & 237,5 & 1,8 & 3,5 & 7,8 & 10,4 \\
\hline 2011 & 218,7 & 1,2 & 3,7 & 9,1 & 12,2 \\
\hline 2012 & 177,9 & 1,7 & 4,2 & 9,8 & 14,8 \\
\hline
\end{tabular}

As is seen from the Table 3, the calculated values differ from actual values of income tax returns for the respective period. The comparative assessment of the taxable capacity calculated differently shows that values of assessments that are based on representative system and correlation-regression analysis differ less from the actual returns by $1.8 \%$ and $4.56 \%$ on average, accordingly. Less accurate are the assessment techniques that base on additive property of the taxable capacity and actual method with both showing an average difference of $13.72 \%$ and $15.5 \%$, accordingly.

It is important to note that the results of Corporate Income Tax Capacity assessment for Tatarstan's insurance market using the described techniques are estimative since they had been obtained by a unilateral analysis of taxation base and cannot be final criteria to determine the tax capabilities of the Tatarstan's insurance market. A general problem of optimal strategies for insurance, consumption and investment in a changing economic environment described by a 
continuous-time regime switching model. [5] Indeed, authors found that the insurance sector in Saudi Arabia and Jordan lags behind most of the other developing economies in Asia and Europe. Also, full implementation of the insurance regulatory Information System (IS) and publication of a clear regulatory ladder could support the taking of early and consistent intervention action on insurance companies. [8]

Moreover, the assessment technique with more accurate results of implementing the insurance market taxable capacity enables calculation of taxable capacity for other taxes subject to payment by all insurance market constituents. The taxable capacity of the insurance market segments may be also analysed as well as in terms of voluntary and compulsory insurance. But this will require suitable statistics data on taxation bases that are not always available. It is for this reason that the insurance market taxable capacity is complicated regarding the regional and local taxes as the tax and statistics forms do not break down by these taxes. Also, the information on taxable items and taxation bases for the members of the Russian Federation is not available.

\section{Conclusions}

Based on the results of the study conducted and summarising the approaches to define the "taxable capacity" that exist in the economic theory and practice, we would propose the following definition of the insurance market taxable capacity: It is a dynamically changing at every specific period set of taxation bases in value terms, which function depends on the effect of tax regulation tools. Therefore, the existing taxation and tax regulation system is not able to accurately predict tax payments that pre-determines its further improvement. More than that evaluation of systemic risk is based on a detailed financial analysis of the insurance industry, its role in the economy, and the interconnectedness of insurers. The primary conclusion is that the core activities of U.S. insurers do not pose systemic risk. [2]

\section{References}

Chen, Y., Chen, Y., Han, J. Correlation analysis on water resources utilization and the sustainable development of economy in Minqin of Gansu Province // Journal of Chemical and Pharmaceutical Research. Volume 6. - Issue 4. - 2014. - pp.157-161.

Cummins, J.D., Weiss, M.A. Systemic risk and the U.S. insurance sector // Journal of Risk and Insurance. Volume 81. - Issue 3. - 2014. - pp.489-527.

Khismatullin, B.R., Kharisova, F.I. Insurance as a way for reducing the market risks level associated with the collective investments // World Applied Sciences Journal Volume 31. -Issue 6. - 2014. - pp.1188-1190.

Kim, S., Lee, J. International macroeconomic fluctuations // Macroeconomic Dynamics. -2014. - Article in press.

Liu, J., Yiu, K.-F.C., Siu, T.K., Ching, W.-K. Optimal insurance in a changing economy // Mathematical Control and Related Fields Volume 4. - Issue 2. - 2014. -pp.187-202.

Luo, Y., Nie, J., Young, E.R. Robust control, informational frictions, and international consumption correlations // European Economic Review Volume 67. - 2014. pp.1-27.

Ma, F., Zhang, Q., Peng, C., Wei, Y. Multifractal detrended cross-correlation analysis of the oil-dependent economies: Evidence from the West Texas intermediate crude oil and the GCC stock markets // Physica A: Statistical Mechanics and its Applications Volume 410. - 2014. - pp.154-166.

Mirah, D., Masa'deh, R.M.T. An analysis of the insurance industry regulator in Saudi Arabia and Jordan through the comparison with insurance industry regulator in the UK // Asian Social ScienceVolume 10.- Issue 3.- 2014.- pp.211-220.

Schiller, F., Prpich, G. Learning to organise risk management in organisations: What future for enterprise risk management? // Journal of Risk Research Volume 17. - Issue 8. - 2014. pp. 999-1017.

Yuan, Q.M., Feng, D., Liu, J. Analysis of the correlation effect of the development of Tianjin marine economy and land economy /I Advanced Materials Research Volume 869-870. -2014. - pp. 648-651.

Zhang, C.L., Tan, Z.L. Correlation analysis on the energy consumption structure and economic growth: Taking Shandong province as an example // Advanced Materials Research Volume 869-870. - 2014. - pp.914-918. 